for congresses or similar purposes, shall on their arrival in a foreign country forthwith get into contact with the competent local representative of Germany, with the Foreign Organization of the Nazi Party and with the branch office of the German Academic Exchange Service, whenever possible. If this be not done, a short report of the reasons must be furnished to me. I take this opportunity to point out that previous decrees concerning foreign journeys are still not always obeyed by all concerned. For example, news of a proposed journey abroad by persons under control of my Office often reaches me first through the German Centre for Congresses. This results in delay, and the person involved not only risks refusal of the necessary foreign exchange, but is also acting in defiance of my orders. I therefore hereby order all controlled by my Office to obey in every detail the Decree on Foreign Travel, and to lay before me, through the official channels, any applications for permission to travel abroad."

\section{German Refugees at the University of Istanbul}

MANY former members of staffs of German universities and other institutes have, as is now well known, either been forced to leave or have voluntarily vacated their posts, for political, racial and other reasons. Some have obtained analogous posts in the universities of countries outside Germany, and we have recently received a list of those who are now working at the University of Istanbul. Among these are Prof. H. Winsterstein (physiology), Prof. M. Brauner (botany), Prof. M. Dember (physicist), Prof. M. von Mieses (mathematics), and nearly thirty others, most of whom have been appointed to chairs in the University of Istanbul. Prof. M. Freundlich, who is at present professor of astronomy, leaves at the end of the academic year for the University of Prague, and Prof. F. Dessauer, professor of röntgenology, is going to the University of Fribourg, Switzerland.

\section{Broadcasting and the Coronation}

Coronation day, May 12, is likely to mark an interesting and notable event in the history of radio communication, for it will witness the most com. plicated outside broadeasts yet undertaken by the British Broadcasting Corporation. The arrangements for the sound programme were explained in the issue of the Radio Times of April 23, while some details of the means to be adopted for televising the Coronation procession were given in World Radio of the same date. On the sound side, apart from the arrangements necessary for the home and Empire programmes, the B.B.C. is providing facilities for about a dozen foreign observers to broadcast commentaries in their own languages direct to their own countries. Two separate control rooms will be established, one at Westminster Abbey for the British programmes and the other at the Middlesex Guildhall for the foreign commentaries. In addition to supplying all the B.B.C. transmitters, the 'home' programme will be distributed to loudspeakers within the Abbey and to others on some of the stands along the route followed by the procession.
By this means, a large number of the public will be enabled to follow the progress of the procession and to hear the service in the Abbey. At the foreign control room, provision is being made for ten separate commentaries in different languages to be fed by land-line to the International Trunk Exchange of the British Post Office, whence the programmes will be distributed to the countries concerned. Some 472 miles of special wiring are involved in the whole installation, which is being carried out by the General Post Office in co-operation with the B.B.C. Engineering Division. This one outside broadcast will involve the use of fifty-eight microphones, and, not least among the technical difficulties, is the necessity of rendering the installation of these as inconspicuous as possible, particularly inside the Abbey.

ON the television side, May 12 will go down in history as the first day on which the direct television of a remotely controlled outside programme has been attempted from the London ultra-short-wave station. For this purpose, the Post Office has installed a special co-axial cable, connecting the Alexandra Palace transmitter with Broadcasting House and the observation point at Hyde Park Corner. In addition, and as a stand-by service, the B.B.C. will use a van equipped with an ultra-short-wave transmitter for feeding the programme to Alexandra Palace. The observation point at Apsley Gate, Hyde Park Corner, was selected on account of its having a combination of several advantages. The afternoon sun had to be behind the 'cameras' and preferably on the objects to be televised; on account of the small receiver screen, the site must allow close-up views on a level with the windows of the royal coach; at the same time, the site must permit an extensive view of the procession as a whole; finally, and not least important, the apparatus must be remote from the huge crowd of the general public. At this site, three 'cameras' will be used for converting the visible scene into the high-frequency electrical currents to be passed along the cable: one of these 'cameras' will be near the main arch at a height of five feet above the pavement; the second will be about ten feet above ground-level and will be used for viewing the crowd and the approach of the procession to within a few yards; the third will be on the other side of the arch and used for following the procession as it disappears towards Constitution Hill. A separate circuit with microphone will be used for providing the sound commentary to this programme. Much of the apparatus to be used on this occasion will be new and untried except on an experimental basis, while very special conditions will prevail on Coronation day itself. The occasion will, however, most decidedly mark the beginning of a new era in television.

\section{British-American Understanding}

Sir Frederick Whyte presided over a discussion, held on March 4 under the auspices of the EnglishSpeaking Union, on "The Contribution of British Schools, Universities and other Educational Bodies to British-American Understanding". The discussion 
was opened by Mr. J. Wickham Murray, who outlined some of the work of the Union in developing contacts between Britain and America. He specially stressed schemes such as the Page Scholarships scheme for men and women teachers, reciprocal scholarships under American direction, exchange of school boys and school masters and mistresses, and assistance given to visitors in both countries. $\mathrm{He}$ indicated, however, that the Union desires now to widen its work and to face the greater responsibilities which the present state of the world suggests it should undertake. To that end it has formed a Research and Discussion Committee, which is seeking the advice and guidance of experts in such fields as foreign affairs, economics, the Press of both countries, and general relationships such as would arise as a result of neutrality legislation and American grievances against British policy. Already meetings of experts in these matters have been held, and, at every meeting, the importance of closer attention to matters of education has been stressed.

Mr. Wickham Murray added that, in thinking it important for British students at school and university to get an accurate picture of Englishspeaking countries, the Union believes that because of similarities in our joint democratic institutions, experiments in those countries might be of greater relevance to Britain than experiments in such very different countries as Soviet Russia, Italy or Germany. In asking the meeting to consider what might be done to improve the contribution of British educational bodies so far as an understanding of problems in English-speaking countries is concerned, he raised the question of possible changes in examination syllabuses, special facilities for providing books on American and Dominion history and affairs, the increase of scholarships and fellowships, and the introduction of special courses on the subject into curricula.

Mr. H. G. WeLLs, president-elect of Section L (Education) of the British Association, who contributed to the discussion, thought there will be no peace in the world until education has been recast into a common basis of understanding throughout the world. He had little confidence in what has been called 'scientific' American, British, or other history. There is but one history-the history of mankind. The world is involved in great issues of human ecology and of economics, but little of these things is taught. He said that we shall have to realizeand it will be a wrench-that much of the history at present taught is stale, unprofitable and out of date. British people are curious about America. They devour American publications; they patronize American films; they are learning to think and speak American; but they are not interested in the history of the Constitution or local points of preCivil War days. The public is willing to react against limited histories and get into general understandings, but the schools hold up this natural development towards the human understanding of the world.

\section{The National Maritime Museum}

THe National Maritime Museum, opened by H.M. the King on April 27, is a notable addition to the public galleries of Great Britain. Housed in a building with historic associations from which can be seen on one side Greenwich Park and the Royal Observatory and on the other the Royal Naval College and the Thames, the Museum will make an appeal to all who take an interest in the history of naval affairs, the growth of the British Empire and the lives of great British seamen of the sixteenth, seventeenth and eighteenth century. It has come into existence through the enthusiasm of the members of the Nautical Research Society, the munificence of Sir James Caird and finally the passing of the National Maritime Museum Act of 1934. The buildings it occupies include the Queen's House finished three hundred years ago, and the wings erected during the nineteenth century when the place was used for the Greenwich Hospital School, now removed to Holbrook, Suffolk. After restoration by the Office of Works, both the Queen's House and the other buildings have been turned into galleries, which now contain the most magnificent series of sea pictures in existence. In addition to the portraits, seascapes, and battle scenes, the great Macpherson collection of prints, drawings, etc., there are beautiful models of ships of the various periods, collections of navigational instruments and a spacious library. No attempt so far has been made to illustrate the great revolution in maritime affairs during the nineteenth century or the historic events of more recent times, but these no doubt will be taken into consideration in due course. The thanks of the whole community, no less than those of students of maritime affairs and of marine art, are due to Sir James Caird, who has made the nation his debtor by the support he has given to the formation of the museum.

\section{The Newcomen Society}

ON April 21, simultaneous meetings of the Newcomen Society took place in London and New York, when two papers were read. The first of these was by Dr. A. Raistrick, and was entitled "The Steam Engine on Tyne Side, 1715-1778" and the second was by Prof. J. W. Roe on "Interchangeable Manufacture". Dr. Raistrick's paper was based on the records preserved by the North of England Institute of Mining Engineers, Newcastle-upon-Tyne; these records consisting largely of "View books" compiled by the colliery 'viewers', the forerunners of the present-day mining engineers. The reports of the 'viewers' contain much information as to the flooding in the mines and the cost of the engines and the pumping. By means of the various papers, Dr. Raistrick has been able to trace the erection of no fewer than 104 'fire engines' built between 1733 and 1778, before the improved engines of Boulton and Watt came on the scene. A rough figure for the first cost of an engine with a 33 in. cylinder was about $£ 1,200$ and the annual cost of working it $£ 400$. Though 13 engines were built between 1715 and 1733 , all of the Newcomen type, it has been impossible to 